\title{
THE GRAPE PHYLLOXERA PLAGUE AS A NATURAL EXPERIMENT: THE UPKEEP OF VINEYARDS IN CATALONIA (SPAIN, 1858-1935)
}

\author{
By Marc Badia-Miró, EnRIC Tello, Francesc VAlls and RAMON GARRABOU* \\ Catalan Open University, University of Barcelona and Autonomous University of Barcelona
}

We present a comparative analysis of the impact and outcome in Catalonia of the wine rush and crash unleashed by the spread of the Grape Phylloxera plague in Europe (1865-1890). In order to explain why many rural districts in the provinces of Barcelona and Tarragona were able to resume winegrowing after the plague, while most in the provinces of Girona and Lleida were not, a statistical model is used to check the economic resilience of the Catalan districts to the external ecological and economic shock. The model combines the population densities as a proxy of the opportunity cost in labour allocation, the demand pull of commercial growth measured by the time-distances to the city of Barcelona, and the agroclimatic land's suitability for growing vines, as measured by the Hugling and Winkler indices or the mean slopes of land. After comparing the vineyard allocation in every district in 1860, 1889 and 1920, these variables are used to explain the differing capacities to endure the Phylloxera plague in Catalonia.

JEL categories: N53, N54, Q17, Q54, Q56, R14, R40

Keywords: Spain, Phylloxera plague, vineyard specialization, factor endowment, timedistances, ago-climatic land suitability

The Grape Phylloxera plague was an ecological external shock, and at the same time a deep economic crisis in the European wine production which led to a new start. ${ }^{1}$ For winegrowers both the ecological and economic impacts were closely related to the first globalization process experienced before the First World War. The insect that started killing the French vines in 1863 had arrived from America as one of the bioinvasions channelled through the "Columbian biological exchange». ${ }^{2}$ By the end of the $19^{\text {th }}$ century the plague had ravaged every old European grapevine. The recovery of European wine production and exports was only possible through another «Columbian exchange» through the use of American varieties of vines, which had coevolved with the Phylloxera insect for three centuries, by grafting them onto the rootstocks of old European ones in order to replant new vineyards resistant to the plague that might keep

\footnotetext{
* This work is part of the research project on the Hidden Sides of Economic Development. Energy, LandUse And Global Change in The Western Mediterranean Region (SEJ2006-15108-C02-01/GEOG) directed by Enric Tello at the University of Barcelona, and financed by the Spanish Ministry of Science and Innovation with ERDF funds. We thank the useful comments and suggestions made by James Foreman-Peck and the other participants to the Pre-conference of the Session on Responses of Economic Systems to Environmental Change: Past Experiences at the $25^{\text {th }}$ World Economic History Congress, organized by Jean-Pascal Bassino and Pierre van der Eng in Aix-en-Provence on January 2009. We also thank Alfonso Herranz-Loncán for his econometric advice. None of them are responsible for our own mistakes.

${ }^{1}$ Garrier, Philoxéra; Pan-Montojo, Bodega; Paul, Science.

${ }^{2}$ Crosby, Columbian; McNeill, Plagues; Diamond, Guns.
} 
the traditional wine tastes. This large-scale replant had to be undertaken in a newly integrated highly competitive global agrarian market.

For an economic and environmental historian the Grape Phylloxera plague can be seen as a «natural experiment», that enables us to test the economic impacts and reactions of a sudden ecological shock by using the comparative method. ${ }^{3}$ The advance of the plague from the South of France in the 1860s to all over Europe in the 1890s ravaged many parts of the regions previously specialized in wine production (Map 1). This created a succession of wine rushes in different areas, where new vineyards were suddenly planted to substitute for French wines until the plague reached them. The waves of wine rushes and crashes created an economic environment of high price volatility, a trend of relative price cuts and rising unit costs in an atmosphere of strong social unrest that became the specific viticulture path into the global agrarian crisis at the turn of the $19^{\text {th }}$ and $20^{\text {th }}$ centuries (Graph 2). ${ }^{4}$

Eventually, only some European winegrowing regions were able to overcome the economic impacts of the Phylloxera plague. In order to recover after the ecological shock they had to adapt wine production and exports to the price volatility and rising unit costs experienced during the first agrarian world crisis. Understanding why some of them succeeded while others failed may provide some interesting answers to the question about how an economic activity can react to a sudden external ecological shock. We focus our analysis on Catalonia (Northeast Spain), contrasting the ability to endure and recover from the plague shown by the main winegrowing districts in the provinces of Barcelona and Tarragona, against the failures experienced in the districts of Lleida and Girona.

\section{CATALAN VITICULTURE BEFORE AND AFTER THE PHYLLOXERA}

What happened in Catalonia during the plague and afterwards? The four Catalan provinces reacted in different ways to the sudden wine rush from the 1860 s to the mid $1880 \mathrm{~s}$, and then to the complete ruin of all vineyards (Graph 3; notice that in 1880-84 data is only available for the provinces of Barcelona and Tarragona). The provinces of Barcelona and Tarragona, where vineyard specialization had taken root in a long-lasting process that started as early as the $17^{\text {th }}$ century, did not experience a dramatic increase in new plantations when the French vines became ravaged: rising only $16.4 \%$ and $15 \%$ from 1860 to 1885 . Then, following the death of all the old grapevines, winegrowers were able to replant and upkeep nearly as many hectares of new vineyards as before the plague: in 1935 there were $6.4 \%$ more hectares planted with vines in Barcelona than in 1860 , and only $1.1 \%$ less in Tarragona.

Things evolved differently in the other two provinces, which in 1860 accounted for less than one third of the Catalan acreage planted with vines (Map 5). The frontier province of Girona was obviously the first one to be hit by the plague coming from France in 1878, allowing almost no time for a sudden big rush before the death of their grapevines. ${ }^{5}$ There, winegrowers were only able to replant one third of the acreage of vineyards that existed in 1860 . The province of Lleida experienced the highest increase

\footnotetext{
${ }^{3}$ Diamond, Collapse, p. 17: «-i.e., to compare natural situations with respect to the variable of interest».

${ }^{4}$ Garrabou ed., Crisis Agraria; Van Zanden, First Green Revolution; Campbell and Overton ed., Land; Koning, Failure of Agrarian Capitalism; Simpson, Long Siesta, and Agrarian Crisis; Persson, Grain Markets.

${ }^{5}$ Piqueras, Filoxera en España.
} 
of new plantations that tried to substitute for the vacuum of French production and exports from 1860 to 1885 , and nearly doubled the area planted with pre-Phylloxera vines until the plague reached and destroyed them. But afterwards, winegrowers were only able to replant with resistant varieties less than half the hectares of vineyards that existed in Lleida in 1860 (Graph 3 and Map 5).

Thanks to technical improvements made by winegrowers mainly in the province of Barcelona, through the increase in manuring and the use of chemical fertilizers, the hectolitres of grape juice produced increased even more than the acreage of new vineyards planted after the Grape Phylloxera plague. The mean yearly wine production was 33\% higher in 1930-34 than in 1890-94, while the hectares planted with grapevines had increased by $28 \%$ (Table 4 ). The recovery of vineyard specialization from the Phylloxera plague went beyond a simple restoration of an earlier regime, especially in the province of Barcelona. From 1890 onwards, Catalan winegrowers and wine industries succeeded in connecting their increasing wine production with the new emerging export market of Mediterranean agricultural goods to north-European and north-American consumers. These technical and commercial improvements were part of the pool of innovations that enabled farmers all over Europe to overcome the agrarian crisis at the end of the $19^{\text {th }}$ century and during the first third of the $20^{\text {th }}$.

However, as we have seen, other Catalan winegrowers in the provinces of Lleida and Girona were unable to endure the Phylloxera plague and restart winegrowing. The vineyard acreage peaked in 1885 , with 367,445 hectares planted in Catalonia $(58,961$ more than in 1860 , in spite of the 33,670 hectares already ravaged by the plague in Girona). From 1885 to 1935 nearly ninety thousand hectares were lost only in the province of Lleida, out of the 109,317 hectares formerly planted with vines that disappeared in Catalonia in the meantime. Here we come to our main question: why were so many winegrowers throughout counties located in the provinces of Barcelona and Tarragona able to overcome the plague and keep most of their vineyards, while the majority of them in the provinces of Lleida and Girona failed and gave up this activity?

A simple comparative analysis seems to discard the entrepreneurial innovations developed as institutional responses to the general agrarian crisis at the end of the $19^{\text {th }}$ century as the answer, such as the spread of cooperatives. We know that cooperatives appeared in all four Catalan provinces, and their activities in organizing commercial channels to sell outputs or buying new inputs were developed in olive oil and cereal production as well as in winegrowing. ${ }^{7}$ We also discard natural endowment taken as a simple encompassing answer, although we consider that agro-ecological features did play a role that has to be taken into account together with other economic factors. For example, all the rural districts in the province of Girona, and also the eastern ones in the province of Barcelona, receive a higher amount of rainfall than the rest of Catalonia. This might have allowed them to overcome the agrarian crisis at the end of the $19^{\text {th }}$ century with a wider range of agrological options, instead of having to resume winegrowing.

Our hypothesis tries to search for the answer in economic and socio-environmental history. We consider that the most apparent difference between the Barcelona and Tarragona provinces that succeeded in enduring the plague, and the ones of Lleida and Girona that failed, was this: vineyard specialization had taken root step by step,

\footnotetext{
${ }^{6}$ Carmona, Colomé, Pan-Montojo and Simpson eds., Viñas; Pinilla and Ayuda, Internacional Wine Market.

${ }^{7}$ Planas, Cooperativismo.
} 
throughout a historical process that had started in the $17^{\text {th }}$ century or even earlier. Thanks to such a long-lasting development, winegrowing became a true culture in these specialized rural areas tightly rooted in agrarian societies and cultural landscapes. ${ }^{8}$ The factorial endowment, know-how and skills that had been accumulated enhanced their economic resilience, allowing them to continue winegrowing after the plague.

Things were not the same in the provinces of Lleida and Girona. Until the 1860s the province of Lleida not only had much less acreage of grapevines, but many of them used to be planted in sparse rows between strips of land alternatively sown with cereals or let lie fallow, surrounded by olive or almond trees growing on the margins. This traditional pattern of associated crops in the same pieces of land fitted very well with an age-old agricultural feature of the Mediterranean landscapes, that maintained a small proportion of vineyards as part of an agrarian system devoted to growing the traditional Mediterranean trilogy: always a little oil and wine produced for local consumption, together with as much wheat and barley as possible. What happened in the provinces of Tarragona and Barcelona from the $17^{\text {th }}$ century onwards was something very different: a specialization process linked with increasing commercial exports towards the emerging Atlantic economy.

\section{HOW A COMPARATIVE ADVANTAGE HAD ARISEN}

There is a strong consensus among economic historians that this commercial vineyard specialization, developed in the littoral and pre-littoral districts of Barcelona and Tarragona provinces, played a key role in the relatively early beginning of industrialization and modern economic growth in Catalonia. Since the publication of Pierre Vilar's masterpiece La Catalogne dans l'Espagne moderne (1962), historians and economists have stressed the role played by the spread of vineyards that took place during the $17^{\text {th }}, 18^{\text {th }}$ and $19^{\text {th }}$ centuries. Brandy and wine exports linked the Catalan economy to a large foreign market from which it could import cotton. The possibility of exports deepened regional specialization and offered an increasing number of working people a way to earn their living, thus avoiding the Malthusian fate typically associated with fast population growth. It also increased the rural population's purchasing power and their consumption of industrial textiles, and enabled landowners or their inheritors to accumulate rural savings which were increasingly invested in new trading or industrial enterprises and railways. ${ }^{9}$ This strong historical link between vines and the cotton industry which developed in Catalonia stands in sharp contrast to the trend of «vigne contre draperie» which characterized other contemporary regions such as the French Languedoc. ${ }^{10}$

Many economic and environmental historians also regard commercial specialization in woody crops such as vines, olive or almond trees as a key feature in the available capabilities for the agrarian development in the western Mediterranean basin during the $18^{\text {th }}$ and $19^{\text {th }}$ centuries, where agrarian specialization became a characteristic vehicle for Smithian-type growth. ${ }^{11}$ However, in recent times it has been stressed that the Dutch-

\footnotetext{
${ }^{8}$ Agnoletti ed., Cultural Landscapes; Tello, Garrabou and Cussó, Energy and Land Use; Garrabou, Tello and Cussó, Social Metabolism.

${ }^{9}$ Sánchez and Nadal, Éxito Algodonero; Sudrià and Pascual, Financing a Railway; Valls, Catalunya atlàntica, and Viticulture et Industrialisation.

${ }^{10}$ Fohlen, En Languedoc; Dugrand, Villes et champagnes; Berger and Maurel, Viticulture; Johnson, Industrial Languedoc.

${ }^{11}$ Vries, A modest proposal.
} 
English mode of «agrarian revolution» in the European Atlantic area was impracticable in the Mediterranean bioregion due mainly to its low rainfall. ${ }^{12}$ Therefore, environmental constraints also played an important role in the vineyard specialization developed in southern Europe during the last stage of pre-industrial «organic» agriculture.

The idea of an «organic economy», put forward by Anthony Wrigley and Rolf Peter Sieferle among other scholars, may help to highlight this relationship between the environmental constraints and the economic forces behind the viticultural focus of agrarian development in the western Mediterranean basin. ${ }^{13}$ From a historical standpoint we consider "organic» any agrarian system in which nearly all of the energy and material flows come, directly or indirectly, from the photosynthetic capture of solar radiation. In this «area-based» energy system the entire economy is highly dependent on the biological net primary production that can be attained from the land. ${ }^{14}$ A key feature of this organic agriculture was the bioregional diversity of limiting factors that became bottlenecks for economic development. Consequently, technological and socioeconomic responses to these environmental constraints necessarily had to be different. The bioregional diversity of past organic agrarian developments stands in very sharp contrast to the uniform global tendencies that characterize the great transformation undertaken after the «green revolution» of the $20^{\text {th }}$ century.

One of the main goals of our research project is to conduct a historical analysis of the links between energy efficiency, land-use efficiency and a healthy landscape ecology from the perspective of ecological economics. ${ }^{15}$ Specifically, we intend to assess and explain the role played by market specialization in driving the diverse agrarian systems in the western Mediterranean basin towards a more advanced organic economy prior to the second industrial revolution and the coming of the cheap oil era. From the point of view of ecological economics, trade is usually seen as a two-edged sword: while it has often been a powerful factor in environmental degradation, it can also foster a better allocation of resources which might also be useful for reducing human impact on natural systems. The first outcome may arise from the ecological-scale effect over a set of biophysical flows that become increasingly unlocked, together with the socioenvironmental consequences of a possible unfairness of trade when it entails an unequal ecological exchange. ${ }^{16}$ The second outcome may actually arise through a backward shift of the limiting factors known in ecology or agronomy as «Liebig's minimum», either indirectly, with a product specialization for which each bioregion has a relative «ecological optimum», or directly, by transferring limiting goods from one bioregion to another. ${ }^{17}$ Economic and environmental historians can contribute to a clearer assessment of this complex and often ambiguous relationship between trade, economy and ecology, through the comparative analysis of different historical paths of commercial specialization and globalization.

\footnotetext{
${ }^{12}$ González de Molina, Environmental constraints; Garrabou, Conflict and environmental tension.

${ }^{13}$ Wrigley, Poverty; Sieferle, Subterranean Forest; McNeill, Something New; Krausmann, Schandl and Sieferle, Socio-Ecological Regime Transitions.

${ }^{14}$ Fischer-Kowalski and Haberl eds., Socioecological Transitions.

${ }^{15}$ Marull, Pino, Tello and Mallarach, Loss of Landscape Efficiency.

${ }^{16}$ Hornborg, McNeill and Martínez Alier eds., Rethinking Environmental History.

${ }^{17}$ Grigg, Dynamics of Agricultural Change, p. 47-67. Ecologists have dismissed the simple theory that every ecosystem tends towards a single «climax», and that every external disturbance would only move it back from its own «equilibrium» end. For each territory there is not a single natural «vocation» but rather a set of possible outcomes. Therefore, any «ecological optimum» must be understood only as a relative bias within an open range of possibilities.
} 
We intend to contribute to this area of research by analysing the scope of trade in Catalonia in the production and consumption of staple agrarian products during the second half of the $19^{\text {th }}$ century. Having reconstructed the energy balances of the agrarian system prior to 1860 in a series of local case studies so as to compare them with current values, and having assessed the changes in land-use and its impact on landscape ecology, we now aim to identify the turning points that transformed a specialized Catalan agriculture into a globalized one before and after the agrarian crisis at the turn of the $20^{\text {th }}$ century. ${ }^{18}$ Three main features distinguished the agrarian specialization in brandies, wines and sparkling «cava» developed in the Catalan provinces of Barcelona and Tarragona. After having started very early in the $17^{\text {th }}$ century, it advanced slowly but steadily during the $18^{\text {th }}$ and $19^{\text {th }}$ centuries until the sudden Phylloxera rush and crash which was eventually overcome. Secondly, winegrowing was always combined with cereals and other crops in several types of complex agrarian landscapes, which were hardly ever devoted to monoculture. Third, the intensity of vineyard specialization remained diverse locally, and sometimes changed municipal location throughout its long history.

Following the qualitative interpretations proposed by many Catalan historians, using the traditional tools of comparative analysis based on case-studies and descriptive statistics, we began by figuring out a number of variables in order to build a model to explain agrarian vineyard specialization in the province of Barcelona and the rest of Catalonia in the mid- $19^{\text {th }}$ century. We have assembled all available data on vineyard acreage in the 35 districts of the four Catalan provinces in 1858-60, 1885-89 and 1922. We have also incorporated other available statistics on population densities, and estimations at a district level of the heliothermal indices of Huglin and Winkler that assess the agro-climatic local suitability for winegrowing, together with the weighted average in the slope of lands. Building this historical model to explain the upkeep of vineyard specialization has required the complementary skills and efforts of a team of researchers made up of historians, economists, agronomists and ecologists that are now working together in our research project.

We started building and applying this econometric approach to explain the local differences in vineyard or cereal specialization around 1860 in the nearly three hundred municipalities of the province of Barcelona. A first statistical set of tests is already in print in a book on The impact of markets in the management of the rural land edited by Gérard Béaur and Vicente Pinilla, where we use a model that combines the «Boserupian» push of population increase (measured with the previous population growth from 1718 to 1860 ), the demand pull of a «Smithian-type» of growth (measured using the terrestrial distances to the nearest seaport), and the agrological land's suitability for sowing grain or growing vines (as measured by mean rainfall, slopes and frost risk). This historical model does not aim at explaining all types of vineyard specialization in every period of time or geographic location, but the role played by this specific set of factors throughout the long-lasting spread of vines in the municipalities of the province of Barcelona that led to a particular organic-based agrarian economy during the second half of the $19^{\text {th }}$ century. ${ }^{19}$

\footnotetext{
${ }^{18}$ Pomeranz, Great Divergence; Williamson, Globalization.

${ }^{19}$ For an epistemological and methodological approach to this kind of modelled historical explanation see Daniel Little's idea of «meso-history» [Accessed 27 May 2009] Available on-line URL: http://www.changingsociety.org/ChangingSociety/Research page.html).
} 


\section{POPULATION GROWTH AND AGRARIAN CHANGE IN AN «ADVANCED ORGANIC» ECONOMY}

However, as Ester Boserup pointed out, the relationship between population growth and agricultural innovation is complex and changeable: while in some range the increase of population density becomes an important driving force for the development of more intensive land-uses, such as the Mediterranean viticulture, beyond a certain threshold further increases in population density become related to the development of industrialization and urbanization that may limit or even question the winegrowing specialization by increasing the opportunity cost of labour. There is also a lower threshold of densities below which the «Boserupian» population pressure stops leading to agricultural intensification, and favours other more extensive land-uses such as cereal crops. ${ }^{20}$ We know that between 1860 and 1920, Catalonia, and especially the province of Barcelona, saw the consolidation of its early industrialization. Thus we need to establish with some accuracy the margin of variation in population density from which we can still expect a positive relationship between population growth and winegrowing specialization, in order to differentiate them from an upper threshold of population densities beyond which the link between the two variables may become insignificant or even negative.

We take the amount of labour required to cultivate a hectare of vines, compared with the labour needed to crop a hectare of cereals, as the crucial data to estimate the range of land-labour ratios that could determine a factor endowment favourable to viticulture. We know through a detailed study we made on the Land-Time Budget Analysis (LTBA) of a rural municipality in the province of Barcelona that around 1860 one hectare planted with vines required 73 man-equivalent working days a year, whereas in a rather intensive cropping of cereals and legumes without fallow practised in the same area only 42 working days were needed at the time. ${ }^{21}$ Another very detailed study on the economic accounting of a vineyard farm in the same province between the 1920s and 1930s tells us that technological innovations adopted after the Phylloxera plague had increased by $30 \%$ the labour required by the new viticulture, up to 94 annual manequivalent working days a year per hectare. ${ }^{22}$ However, other contemporary sources also tell us that the extensive cultivation of cereals with fallow practiced in inland Spain only required 25 working days per hectare a year. ${ }^{23}$ This was also the case in the Catalan province of Lleida, were population densities matched the Castillan ones from 1860 to 1920 .

Assuming that the agricultural active population worked on average 8 hours a day during 240 days a year, and that there was the same 0.37 ratio of agricultural active people over the total population that we get in the abovementioned local case study on LTBA towards 1860, we can calculate from the labour required for a unit of land devoted to grow vines, an optimal population density that ranged between 0.8 and 1 hectare of cropland per inhabitant. This would have meant between 82 and 105 inhabitants $/ \mathrm{km}^{2}$ if all the land had been covered with vineyards, which of course is not plausible except in very specific local cases. In order to calculate the mean optimal population density for growing vines a proportion of vineyards over the total extension of land must be applied, which varied greatly from one village to another. Taking as a reference the averages of cropland acreage that in Catalonia ranged between 30 and

\footnotetext{
${ }^{20}$ Boserup, Population.

${ }^{21}$ Garrabou, Tello and Cussó, Ecological and Socio-economic functioning.

${ }^{22}$ Anonymous, La revisió dels contractes de parceria, p. 12.

${ }^{23}$ Carrión, Latifundios, p. 324.
} 
$40 \%$ of the total provincial size from the years $1860 \mathrm{~s}$ to the $1880 \mathrm{~s}$, an optimal population density for viticulture would have hovered between 25 and nearly 40 people per $\mathrm{km}^{2}$.

This fits very well with the data we have from the available census (Map 6). While population densities remained around 25 inhabitants $/ \mathrm{km}^{2}$ in the province of Lleida, mainly devoted to cereal crops except during the short-lived wine rush during the Phylloxera infestation of French vines, all the other Catalan provinces already had population densities above 40 inhabitants $/ \mathrm{km}^{2}$ from 1860 to 1920 . However, only in the province of Barcelona they had climbed from 94 to 175 inhabitants $/ \mathrm{km}^{2}$, or from 1,978 to 5,662 in the Barcelona district, due to the advance of industrialization and urbanization. It is interesting to note that according to Ester Boserup 65 inhabitants $/ \mathrm{km}^{2}$, or one and a half hectares per person in most of rain-fed agricultural areas of the world is the maximum level of population density that can be sustained by a highly intensive agrarian system. Only an urban-industrial economy can maintain population densities higher than that. ${ }^{24}$

Let us imagine for a moment what it would have meant to rely on only 1.5 hectares per person to feed the local population and provide them with fuelwood and pasture with an organically based intensive agricultural system, and in a Mediterranean bioregion subject to low rainfall and where keeping livestock and obtaining fertilizers became severely limiting factors. As in any type of organic agriculture, an innovative response had to deal with two difficult side-effects: the scarcity of fertilizers and firewood. The Mediterranean solution of planting vineyards helped to prevent firewood and manure becoming bottlenecks that might have halted the progression towards a more intensive land-use pattern. Vines were planted mainly by poorer peasants in poor, sloping land, and no manure was put on them after planting. However, the specialization in vine cultivation was only partially maintained, which enabled the polycultural landowners of the typical scattered Catalan farms to use most of what little manure was available on the better soils used primarily for cereals and legumes, together with some fruit trees, vegetables and hemp. After vintage time, even the green shoots of the vines were used as fodder for sheep, which in turn produced the muchneeded manure to fertilize other crops. Vines were also pruned to provide a valuable substitute for increasingly scarce firewood. ${ }^{25}$

The high transportation costs before the railway reinforced the role played by local and regional endowment of land and labour, both in ecological and economic terms. ${ }^{26}$ In that sense, the location of every district must have had a deep impact on the economic accessibility to foreign markets. For the same reason, the extension of railways should have led to a dramatic reduction in transport costs taken as a measure of access to markets. ${ }^{27}$ The dataset on time-distances we have assembled clearly show this drastic reduction of the journey time to Barcelona experienced in Catalonia between 1856 and 1920 (Map 8). According to our data, in several districts of Lleida and Girona the arrival of the train divided by four or five the existing time-distances to the city of Barcelona. On average the spread of the railway network divided by almost three the time needed to travel from any Catalan district to Barcelona. While in 1856 only 10 districts were less than 6 hours away form the harbour of Barcelona, in 1920 already 24

\footnotetext{
${ }^{24}$ Boserup, Population.

${ }^{25}$ Tello, Garrabou and Cussó, Energy and Land Use.

${ }^{26}$ Fischer-Kowalski, Krausmann and Smetschka, Modelling scenarios.

${ }^{27}$ See for Catalonia Pascual, Caminos de la Era Industrial; and for Spain, Herranz-Loncán, Spatial Distribution.
} 
out of 35 were. After a change of this magnitude we might expect that the distance to Barcelona ceased to be a critical factor for the location of vineyards. However, a comparison between Maps 5 and 8 reveals that vineyard location did not change so much in spite of the dramatic cuts in transport costs experienced from 1880 to 1920. This could mean that a path dependency kept alive the comparative advantage previously accumulated by those regions that already enjoyed a vineyard specialization before 1860 .

\section{OUR HYPOTHESIS: HISTORY, MARKET ACCESS AND AGRO-ECOLOGY MATTER TOGETHER}

As we have said, the vineyard specialization of the Catalan districts could be explained by three main sets of variables: agro-climatic endowment for winegrowing, population densities, and time distances to the seaport of Barcelona as an indicator of market access. We are going to test the statistical significance of these factors in order to explain the degree in winegrowing specialization of every district during the whole period from 1858 to 1922 . To do this we propose the estimation of panel data from equation (1):

$$
Y_{i, t}=\alpha_{i}+\beta \cdot X_{i, t}+\varepsilon_{i, t}=\alpha_{i}+\beta_{1} \cdot A G R E C O L_{i}+\beta_{1} \cdot M K A C_{i, t}+\beta_{1} \cdot P O P D E N_{i, t}+\varepsilon_{i, t}
$$

The model is aimed at explaining the percentage of cropland devoted to vineyards $\left(Y_{\mathrm{i}, \mathrm{t}}\right)$ in each district in the whole period, taking into account: the agro-ecological variables $\left(A G R E C O L_{\mathrm{i}}\right)$ such as the indices of Huglin $\left(H U G_{\mathrm{i}}\right)$ and Winckler $\left(E T I_{\mathrm{i}}\right)$ of climatic suitability for vines, or alternatively, the weighted mean slope of land expressed as a percentage $\left(S L O P_{\mathrm{i}}\right)$ seen as a proxy for land suitability to cereal crops and vineyards; the market access $\left(M K A C_{\mathrm{i}, \mathrm{t}}\right)$ assessed by the time-distances in hours to the Barcelona market and harbour $\left(B C N T I M D I S_{\mathrm{i}, \mathrm{t}}\right)$ following the existing roads and railroads; and the population density $\left(P O P D E N_{\mathrm{i}, \mathrm{t}}\right)$ taken as a proxy for factor endowment in land-labour ratios.

First of all, in order to measure the impact of agro-ecological factors on vineyard specialization in the Catalan districts we estimate equation (1) by OLS, incorporating as variables the Huglin $(H U G)$ and Winkler $(E T I)$ indices together with market access and population densities, or alternatively the weighted average of land slopes (Table 9). The results in columns (a) and (b) show that only the latter are significant, while the agroclimatic indices are not. The heliothermal indices of Huglin and Winkler are used world-wide to assess the climatic suitability for growing vines in any region on Earth, and even to predict the effects of climate change on vineyard location. ${ }^{28}$ However, a very important first result of our research has been to check that these indices do not appear significant in the tests, in order to explain the historical vineyard locations in Catalonia from 1858 to 1922 at district level. After having tried them several times in several ways, we have found the solution to the apparent paradox by looking carefully at the Maps 5 and 7. The higher Huglin and Winkler scores are reached on the coastline, especially in the delta of the Ebro river, or in the inland plane of Lleida. However, most of the Catalan districts with a long-lasting vineyard specialization were located in the pre-littoral corridor that lies in between these littoral and inland places. That means two

\footnotetext{
${ }^{28}$ Tonnietto and Carbonneau, Multicriteria.
} 
very important things: 1) the climate zone well endowed for growing vines was and still is broader than the area actually exploited; and 2) although vineyard specialization developed in districts agro-climatically suitable for viticulture, they were not always the most suitable.

The first areas where vineyards were grown to make and export brandies during the $17^{\text {th }}$ and $18^{\text {th }}$ centuries were located in some points of the coastline, near the towns of Mataró and Tarragona-Reus. But later on most of these early specialized locations abandoned viticulture in favour of other more profitable crops or economic activities, except when they had developed a high quality brand. Catalan vineyards moved location towards the pre-littoral corridor while table wines replaced brandy as the main export product during the $19^{\text {th }}$ century. ${ }^{29}$ Ironically, vines became more widespread again in the coastline, as well as in the inland plains of Lleida, only during the shortlived wine rush when the Phylloxera first infested the French vines. After the plague, the centre of gravity of vineyard specialization returned again to the pre-littoral corridor in Southwest Barcelona and Northeast Tarragona provinces.

However, if we replace the climatic indices in the test shown in Table 9 with the weighted average of land slopes in each district, the result in column (b) tells us that this variable becomes significant but has a negative sign, meaning that vines were not planted in the most sloping districts like the ones in the Pyrenees. In a previous model we tested to explain the vineyard specialization achieved towards 1860 in all the municipalities of the Barcelona province, we found that vines used to be planted mainly in poor sloping soils not suitable enough to crop wheat. ${ }^{30}$ According to that, vineyard location can be better explained at a municipal scale by the most unsuitable land for cereals rather than by the most suitable land for vines. Nevertheless, looking at the available data at district level the result found here is the opposite: vines could not be planted in soils with slopes so pronounced as those prevailing in the Pyrenees and other parts of Catalonia. We are faced again with a question of ranges and thresholds. A different result could have probably be found if the weighted average of the slope had been calculated only for cropland, rather than for the total area. Unfortunately, the available cadastral maps do not cover all the municipalities and districts before the 1950s in Spain. Therefore the most relevant statistical result obtained here is to remind us that in assessing agrological and ecological features scale matters.

Anyhow, we come to the conclusion that natural endowment alone can explain neither the spatial pattern nor the historical trends of vineyard specialization in Catalonia during the last three centuries, at least watching it at district level. Socioeconomic factor endowment and travel costs for market access are needed to do that. So after having arrived at this very important conclusion from the first (a) and (b) columns in Table 9, we need to look at the changing socioeconomic variables. In column (c) we conducted a second estimate of the equation (1) by fixed effects for all districts. By construction, in this fixed effects estimation the constant varies for each district, thus capturing the characteristics of every spatial unit. The result shows that the variable of time-distances for access to markets appears significant and with expected negative sign, meaning that commercial specialization in winegrowing continued to be correlated with a better access to the city of Barcelona, in spite of the big improvements in transport facilities. However, population density is not a significant variable in this case (c). As we explained in the preceding discussion on the meaning of different ranges and thresholds

\footnotetext{
${ }^{29}$ Valls, Catalunya atlàntica.

${ }^{30}$ Garrabou, Tello and Cussó, Explaining agrarian specialization.
} 
of population density taken as a proxy for land-labour ratios, we know that the very high densities in the district of Barcelona were clearly related to other types of urbanindustrial economic dynamics since 1860. Therefore, we repeated the exercise taking that district out. The new estimate (d) shows again significant results and the expected negative sign in the variable of access to markets, and this time the population density also becomes significant and with the appropriate positive sign, meaning that up to a point vineyard specialization was positively related to a greater population per unit of cropland.

\section{ON THE ECONOMIC AND ECOLOGICAL RESILIENCE OF A CULTURAL LANDSCAPE: ANY LESSONS?}

Considering the evidence at hand, we believe we have accounted successfully for a great deal of the variability in the specialization in vine cultivation between the districts in Catalonia before and after the Phylloxera plague, in a way that stresses the path dependency experienced by a comparative advantage that had been previously created through a long-lasting historical process. Viticulture became a rooted cultural landscape in these specialized Catalan districts, and this character reinforced their economic resilience to a sudden external shock like the grape Phylloxera plague. If there is any lesson to get here, perhaps it would be to stress the importance of betting for comparative advantages deeply rooted in the differentiated natural, social and cultural fabric of every landscape. Although no commercial specialization will last for ever, this kind of socio-environmental base can enhance the resilience of the economic system against exogenous shocks.

The significant statistical results we have obtained can also be seen as an indirect confirmation of the Heckscher-Ohlin theoretical explanation of commercial specialization, by means of the relative factor endowment of land and labour. However, our main aim as historians is to understand how these different land-labour ratios arose, and why they were kept in the Western Mediterranean bioregion over a long historical period. While the agro-ecological endowments can be seen as almost immobile, the available labour supply was created instead by the relative presence or absence of landless peasants. These poor peasants sought to earn their living working as tenants of a rabassa morta lease on the thin and sloping soils offered to them by landowners. ${ }^{31}$ This peculiar Catalan tenancy contract called rabassa morta lasted until the death of the vines planted by the tenant. The fact that this leasing system became so widespread might be understood as a collective achievement of a very difficult agreement between wealthy landowners and landless peasants. The social conflict over land entitlement between these rabassa tenants and landowners lasted from the $18^{\text {th }}$ century, and until the Spanish Civil War in 1936-39. Nevertheless, the contractual agreements reached between them in the meantime helped to reduce the prevailing agrarian inequality, and channelled the social unrest triggered by this conflict towards creating a more productive rural society. ${ }^{32}$ This may also help to explain why the «Boserupian» push of population growth, combined with the growing inequality in land ownership, seems to have played such an important role that deserves to be better analysed in future improvements of the model. A further discussion is also needed on how to deal with the endogeneity problem that working with these socio-demographic variables may entail.

\footnotetext{
${ }^{31}$ Olarieta, Rodríguez-Valle and Tello, Preserving and destroying soils,

${ }^{32}$ Garrabou, Planas, and Saguer, Sharecropping; Garrabou, Cussó and Tello, Cambio de usos del suelo.
} 
Map 1. The spread of the Grape Phylloxera plague in Europe (1868-1920)

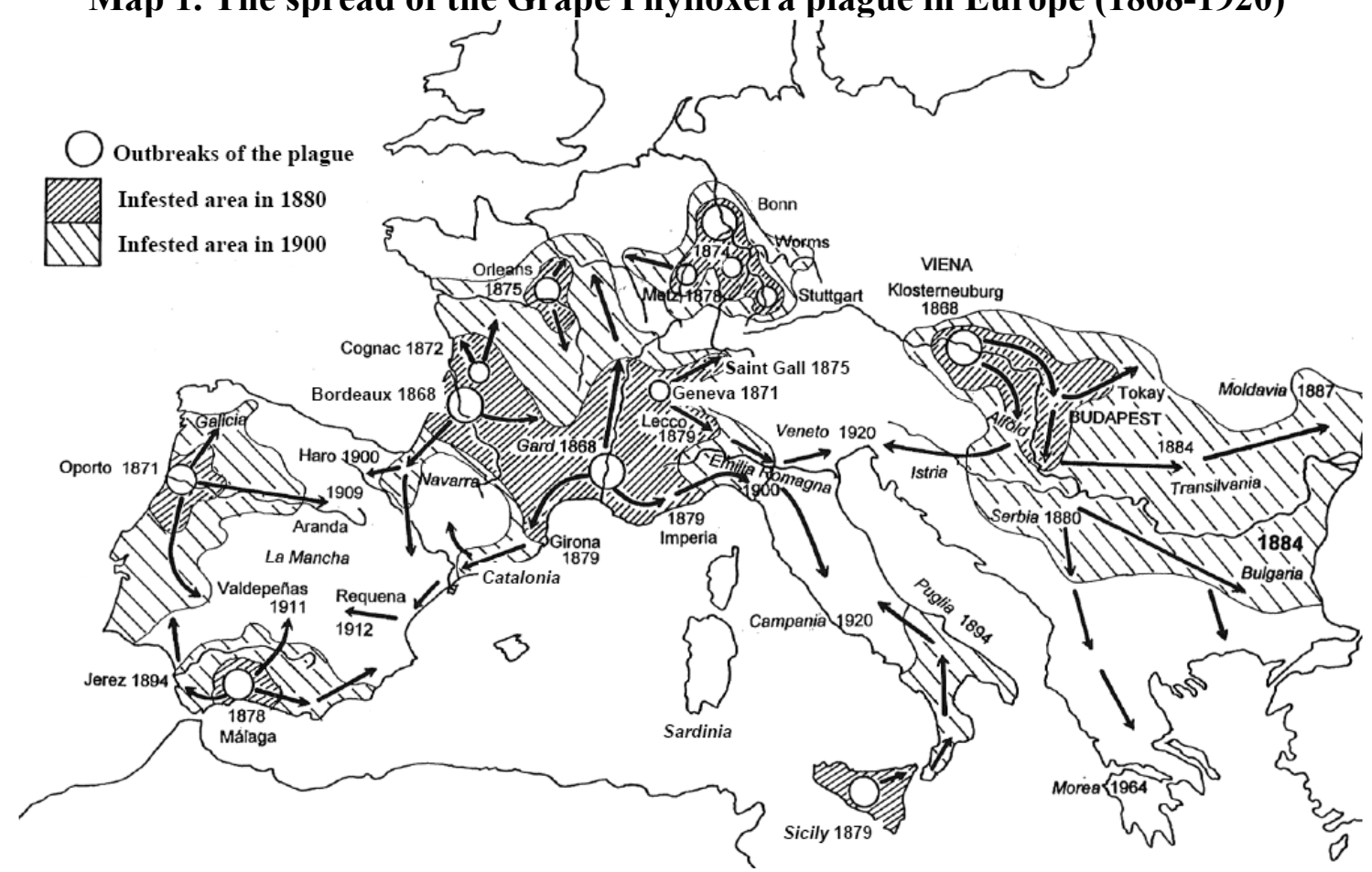

Source: our own, adapted from Piqueras, Filoxera en España, p. 106.

Graph 2. Wine produced in France and Algeria (in millions of hectolitres, left axis) and wine prices in Barcelona (in pesetas per hectolitre, right axis), 1870-1914

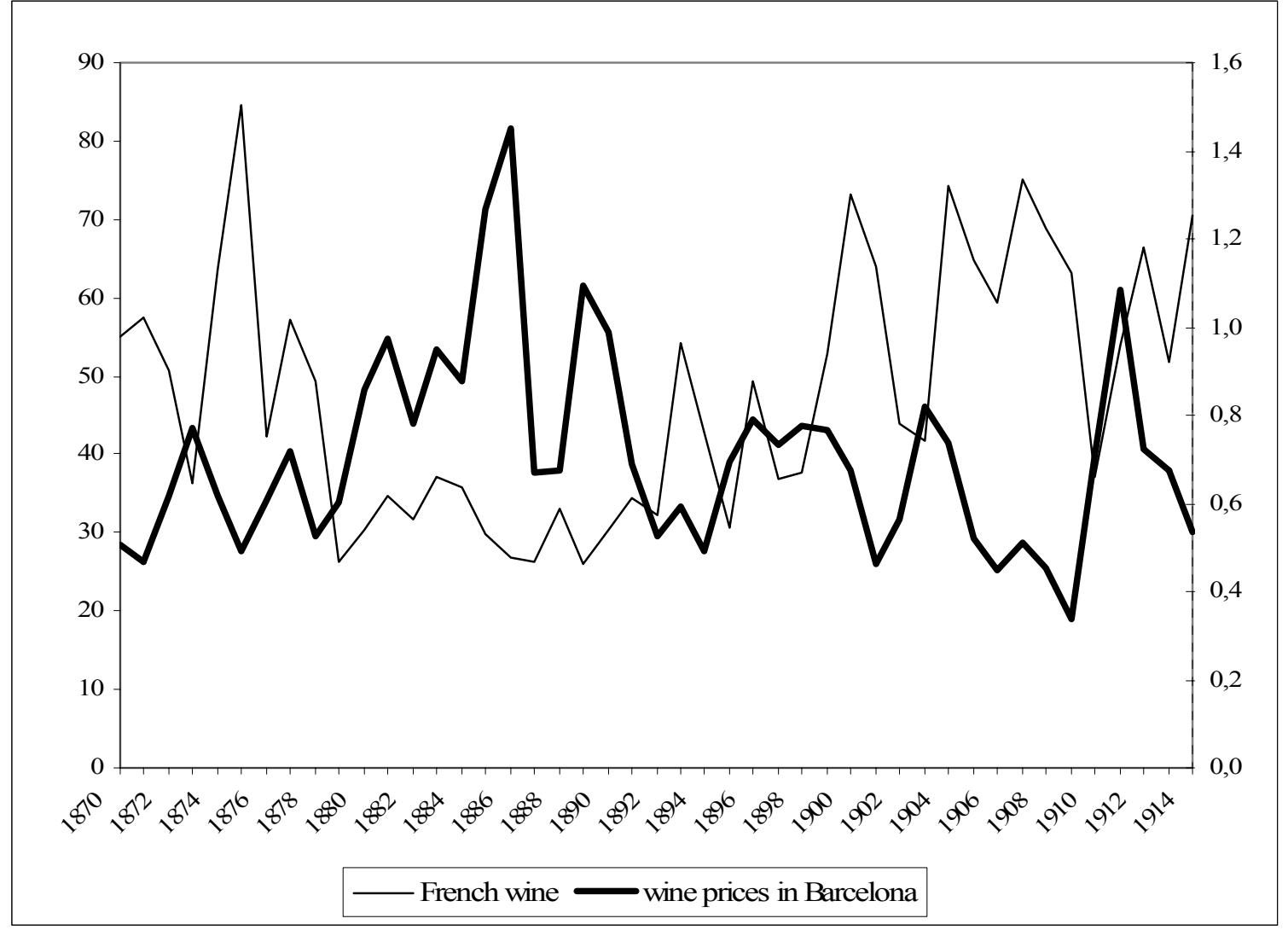

Source: Garrabou, Tello and Cusso, Explaining agrarian specialization; Garrier, Philoxéra, p. 175. 
Graph 3. Land devoted to vineyards in the four provinces of Catalonia in hectares (1860-1935)

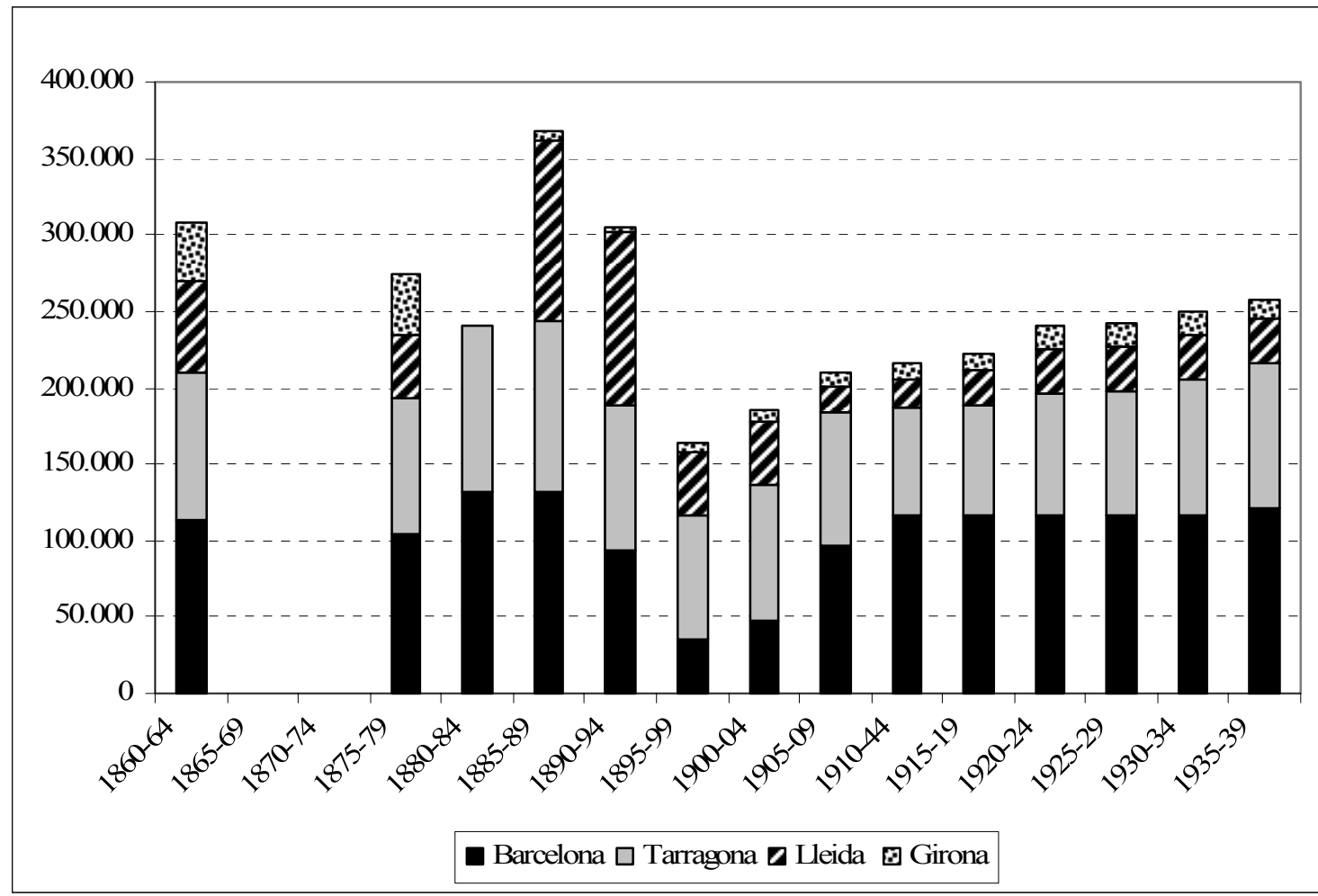

Source: our own, from Moreno, Estadística Territorial; Martínez Quintanilla, Provincia de Gerona, p. 295-297; Llovet Mont-ros, Contribución; Roig Armengol, Memòria; García de los Salmones, Invasión Filoxérica, p. 193; Junta Consultiva Agronómica, Estadística, p. 265-300; Garrabou and Pujol, Canvi Agrari, p. 80-81; GEHR, Estadísticas históricas; Heras and Mas, Viticultura i Fil-loxera; Piqueras, Filoxera en España, p. 135; and Valls, Dinàmica. Notice that in 1880-84 data is only available for the provinces of Barcelona and Tarragona.

Table 4. Five-year mean wine production in the four Catalan provinces (in hectolitres of grape juice, 1890-1934)

\begin{tabular}{crrrrr}
\hline & \multicolumn{1}{c}{ Barcelona } & \multicolumn{1}{c}{ Girona } & \multicolumn{1}{c}{ Lleida } & \multicolumn{1}{c}{ Tarragona } & CATALONIA \\
$\mathbf{1 8 9 0 - 1 8 9 4}$ & $10,330,557$ & 321,856 & $8,499,954$ & $8,623,763$ & $27,776,129$ \\
$\mathbf{1 8 9 5}-1899$ & $4,451,321$ & 460,822 & $3,924,483$ & $6,082,960$ & $14,919,586$ \\
$\mathbf{1 9 0 0 - 1 9 0 4}$ & $9,407,277$ & 811,231 & $3,127,252$ & $6,574,141$ & $19,919,901$ \\
$\mathbf{1 9 0 5 - 1 9 0 9}$ & $9,128,789$ & 831,906 & $1,140,292$ & $7,080,729$ & $18,181,716$ \\
$\mathbf{1 9 1 0 - 1 9 1 4}$ & $12,150,214$ & 850,807 & $1,373,239$ & $8,175,214$ & $22,549,474$ \\
$\mathbf{1 9 1 5 - 1 9 1 9}$ & $18,067,230$ & $1,957,778$ & $1,365,749$ & $9,320,052$ & $30,710,809$ \\
$\mathbf{1 9 2 0 - 1 9 2 4}$ & $21,474,627$ & $2,268,922$ & $1,712,615$ & $12,122,787$ & $37,578,951$ \\
$\mathbf{1 9 2 5}-1929$ & $18,468,333$ & $1,647,409$ & $1,048,112$ & $9,369,795$ & $30,533,649$ \\
$\mathbf{1 9 3 0}-1934$ & $13,773,209$ & 1.207 .384 & $1,120,856$ & $7,768,326$ & $23,869,775$ \\
$\Delta \mathbf{1 8 9 0 - 9 4}$ to $\mathbf{1 9 3 0}-34$ & $3,442,652$ & 885,529 & $-7,379,098$ & $-855,437$ & $-3,906,354$ \\
$\% \Delta \mathbf{1 8 9 0 - 9 4}$ to $\mathbf{1 9 3 0 - 3 4}$ & 33.3 & 275.1 & -86.8 & -9.9 & -14.1 \\
$\Delta \mathbf{1 8 9 0 - 9 4}$ to $\mathbf{1 9 2 0}-24$ & $11,144,070$ & $1,947,067$ & $-6,787,339$ & 3.499 .025 & 9.802 .823 \\
$\% \Delta \mathbf{1 8 9 0 - 9 4}$ to $\mathbf{1 9 2 0}-24$ & 107.9 & 605.0 & -79.9 & 40.6 & 35.3 \\
\hline
\end{tabular}

Source: our own, from GEHR (1991). Regular yearly statistics of agricultural production in every Spanish province only began in 1890 . 
Map 5. Percentage of cropland devoted to vineyards in the districts of Catalonia 1858-64

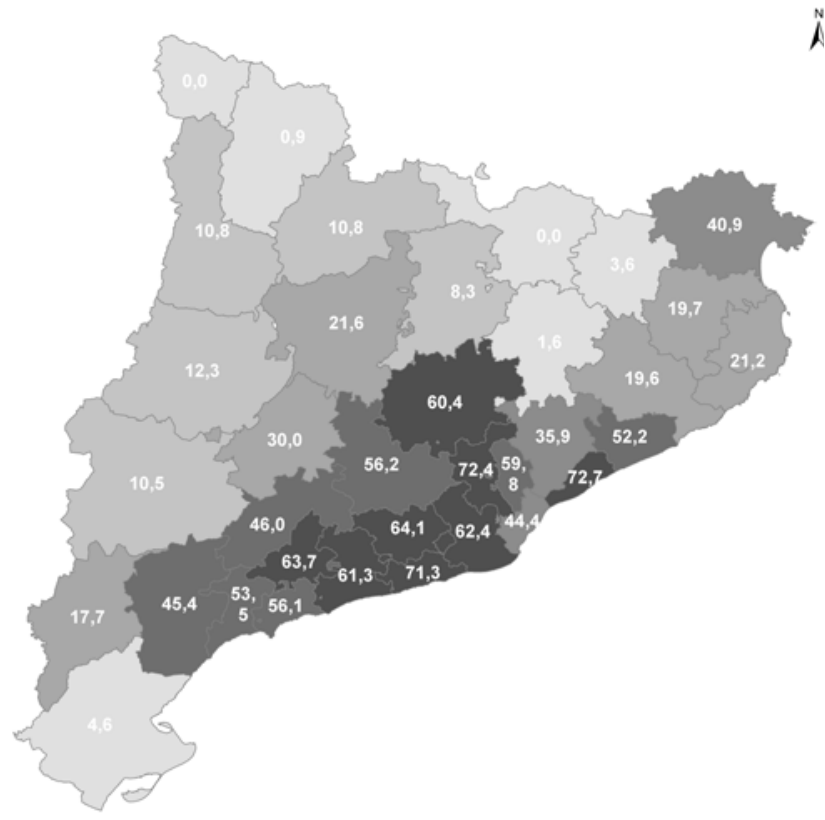

1885-89

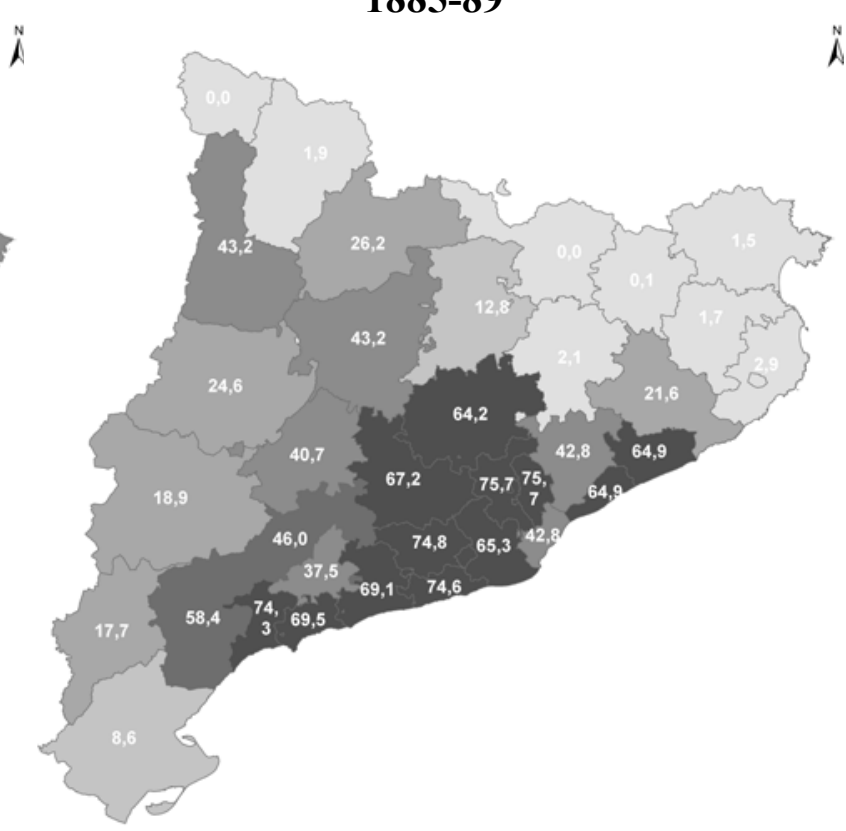

1922

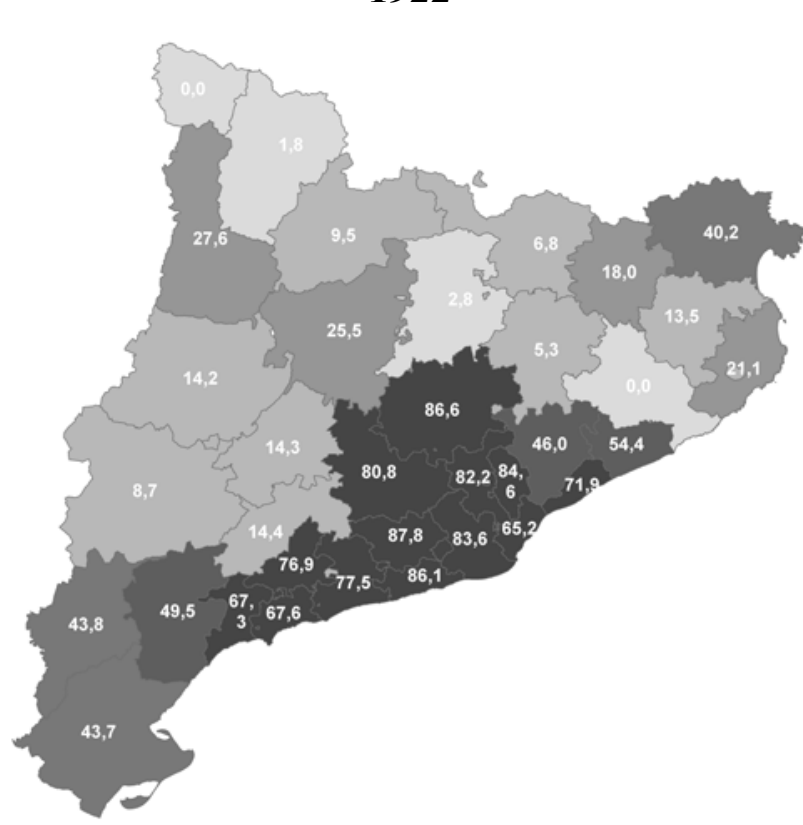

$\tilde{A} \%$ of vineyards in 1858-64 \% of vineyards in $1885-89$

\begin{tabular}{|c|c|}
\hline $0-5$ & $0-5$ \\
\hline $5-15$ & $5-15$ \\
\hline $15-30$ & $15-30$ \\
\hline $30-45$ & $30-45$ \\
\hline $45-60$ & $45-60$ \\
\hline $60-75$ & $60-80$ \\
\hline
\end{tabular}

$\%$ of vineyards in 1922

\begin{tabular}{|l|l|}
\hline & $0-5$ \\
5 & -15 \\
15 & -30 \\
$30-45$ \\
$45-60$ \\
$60-90$
\end{tabular}

Source: our own, from the data and historical sources referred in Graph 3. 

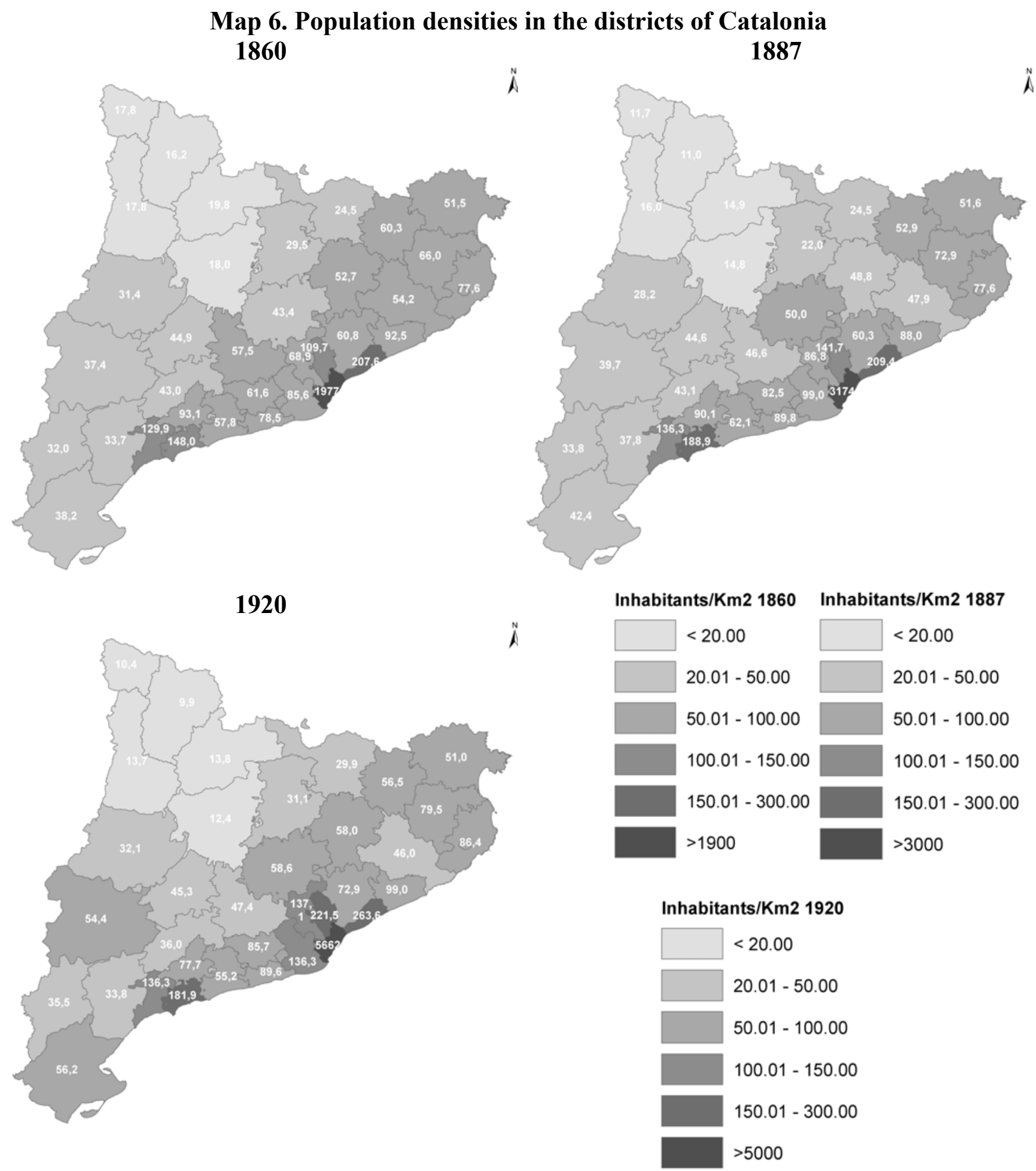

Source: our own, from the data available at the Centre d'Estudis Demogràfics, [Accessed 27 May 2009] on-line URL: http://www.ced.uab.es/index.php?newlang=eng. 

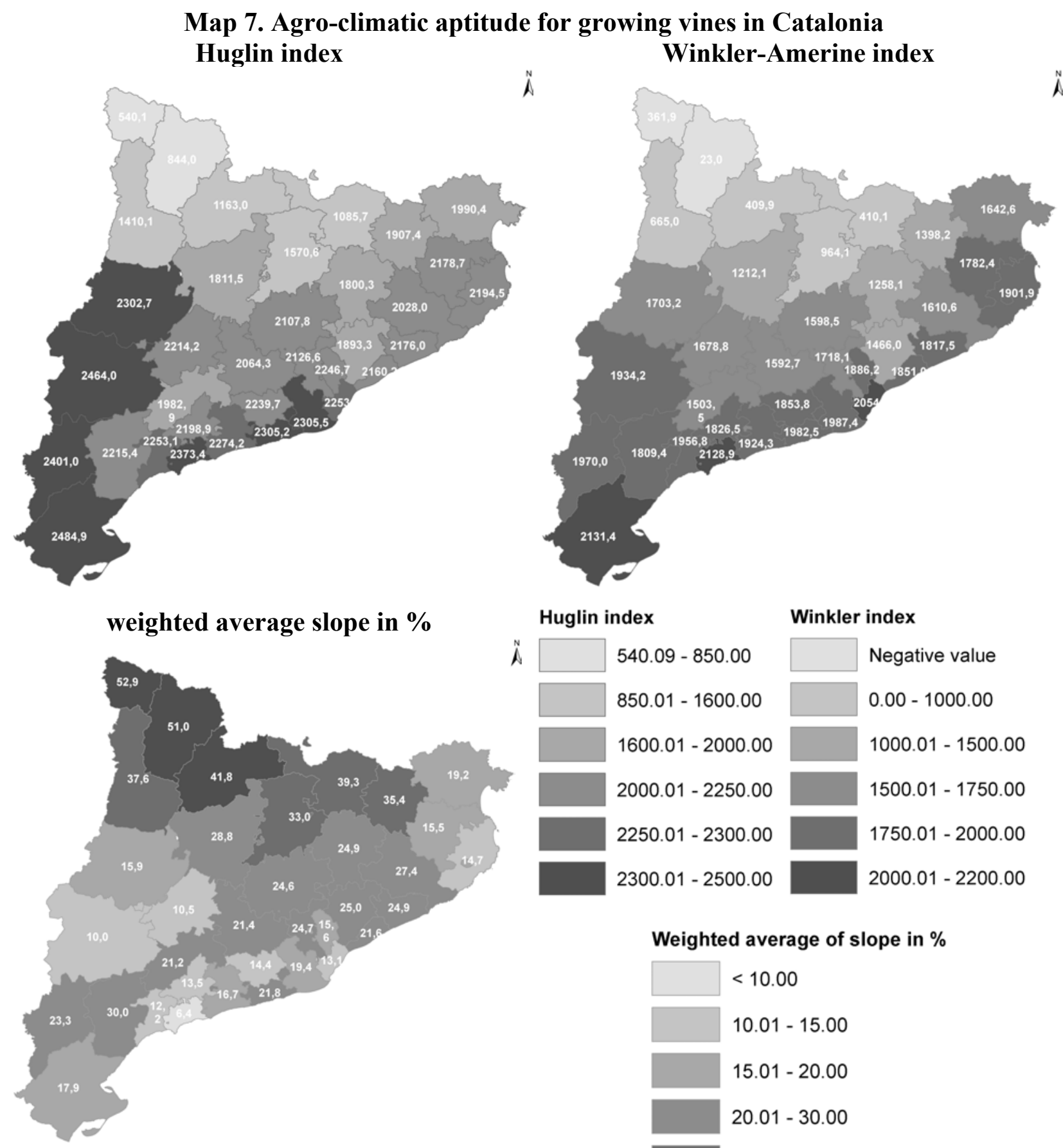

Huglin index

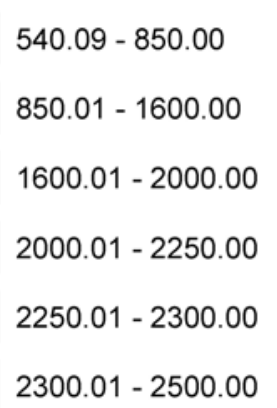

Winkler index
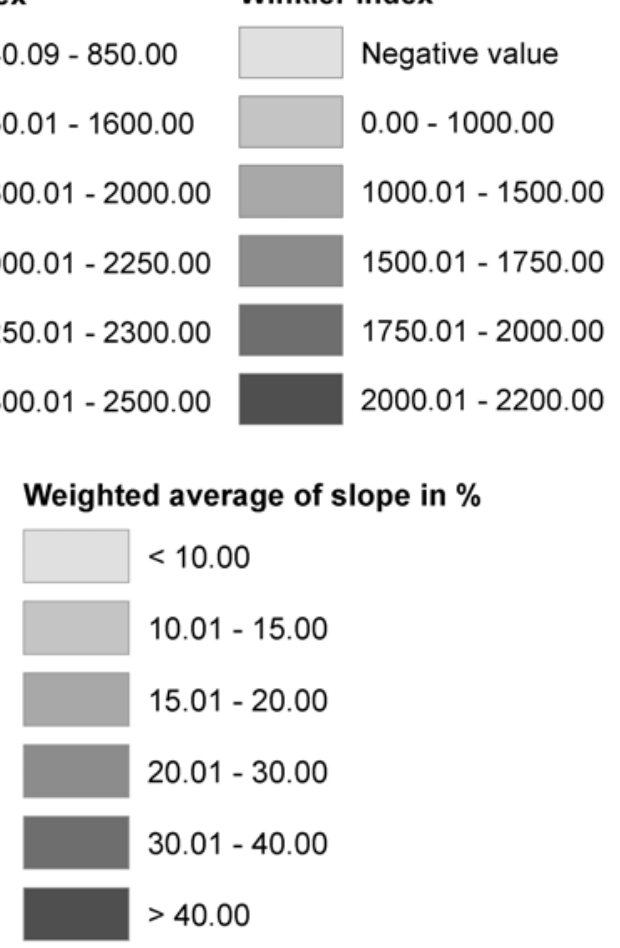

Note: Growing vines requires a Huglin index of at least 1,500 and a Winkler-Amerine index of at least 2,000. The Huglin index of helio-thermal aptitude is obtained by the expression: $I H=\Sigma\left[\left(T_{a}-10^{\circ}\right)+\left(T_{m}-10^{\circ}\right)\right] \mathrm{K} / 2$, where $T_{a}$ is the daily average temperature, $T_{m}$ is the maximum daily temperature during the active period of vegetation, and $K$ is the length ratio of days varying from 1.02 to 1.06 between 40 and 50 degrees of latitude. The Active Thermal Integral $(A T I)$, is calculated by adding the daily mean temperatures above or equal to $10^{\circ} \mathrm{C}$ during the active period of vegetation between March and October: $A T I=\Sigma T_{a}$, where $T_{a}$ is the active temperature. The Effective Thermal Integral (ETI) of Winkler \& Amerine is the sum of effective daily mean temperatures, calculated from the monthly average temperatures multiplied by days of each month during the growing season from April to October: $E T I=\Sigma T_{e}$, where the effective temperature $\left(T_{e}\right)$ is the active temperature $\left(T_{a}\right)$ minus $10^{\circ} \mathrm{C}$.

Source: our own, calculated with GIS by J. Marull, M. J. Cordobilla and F, Rodrígez-Valle for the research project SEJ2006-15108-C02-01/GEOG. A GIS spatial interpolation of a resolution of 180 meters has been done based on the data of air temperature taken from 160 weather stations (one station per $200 \mathrm{~km}^{2}$ ) for the period 1961-1990. 

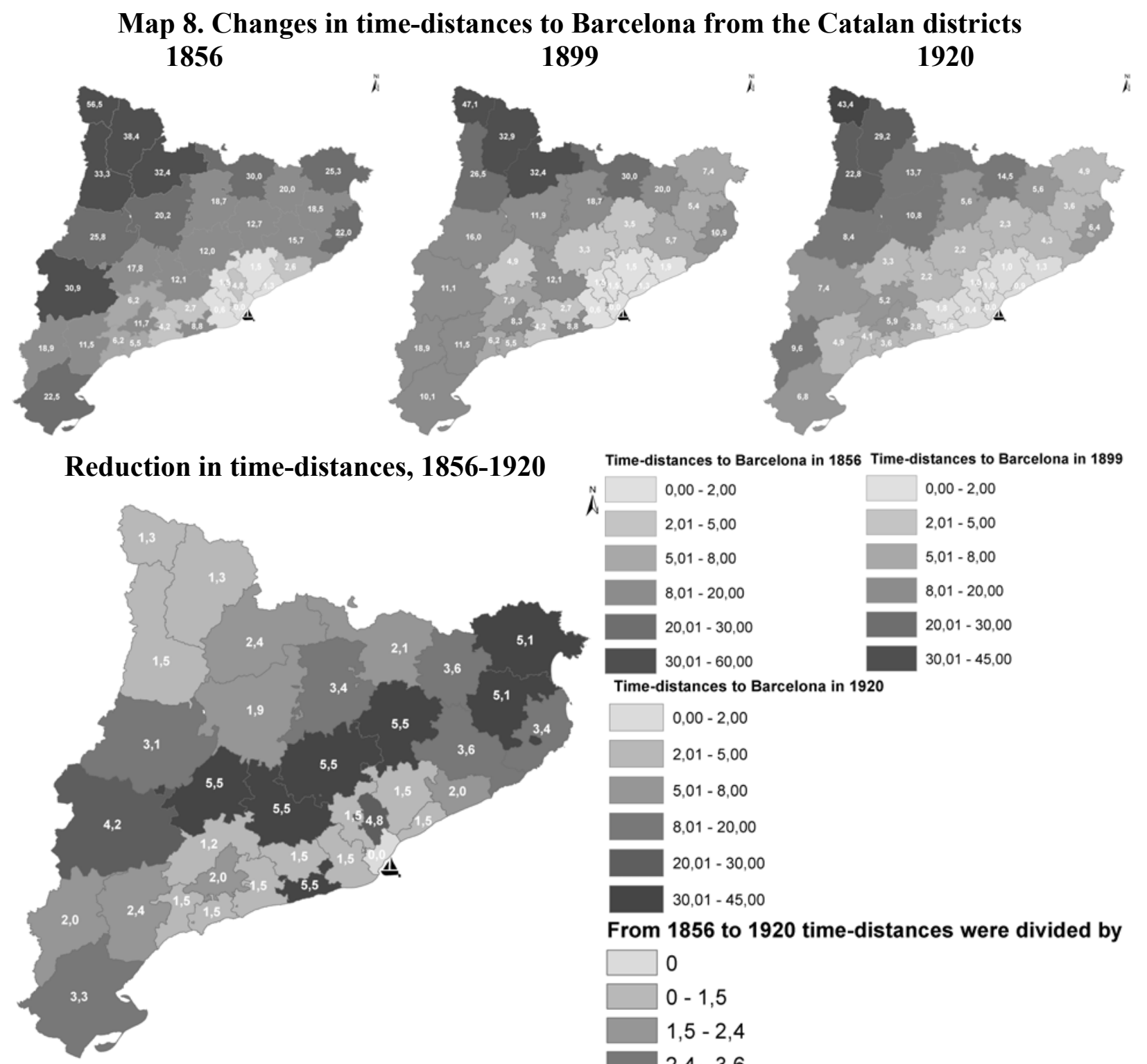

Time-distances to Barcelona in 1856 Time-distances to Barcelona in 1899

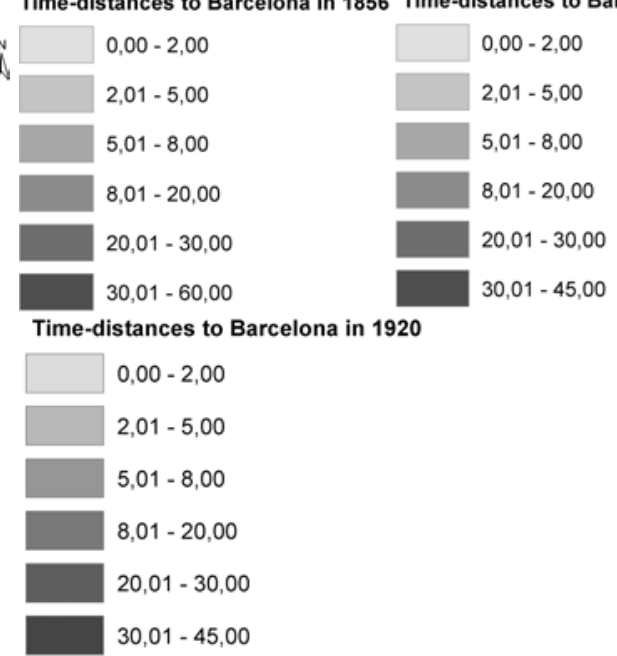

From 1856 to 1920 time-distances were divided by

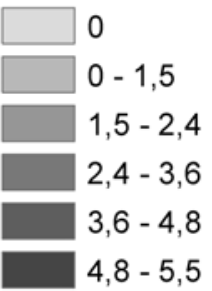

Source: our own. Time-distances before the railway and until 1856 have been taken from these four references: Anonymous, Itinerario; Bertrán Soler, Itinerario; Frígola, Relación; and Estasen, Cataluña. For 1880 and 1889 terrestrial distances have been calculated with GIS by Marc Badia-Miró based on the existing railroads and roads at the time. They have been turned into time-distances by applying the average speed of $4 \mathrm{~km} /$ hour on horseback, 5 $\mathrm{km}$ /hour by cart and $20 \mathrm{~km} /$ hour by a «cheap» railway, according to Sociedad Económica de Amigos del País de Barcelona, Crisis Agrícola y Pecuaria, p. 87. For 1920 the average railway speed has been increased to $30 \mathrm{~km} / \mathrm{hour}$. 
Table 9. Regressions to explain the upkeep of vineyard specialization in Catalonia before and after the Grape Phylloxera Plague

\begin{tabular}{|c|c|c|c|c|}
\hline \multicolumn{5}{|c|}{ Percentage of cropland devoted to grow vines in the districts of Catalonia in 1858-64, 1885-89 and 1922} \\
\hline & $\begin{array}{l}\quad(\mathrm{a}) \\
\text { Combined } \\
\quad \text { OLS } \\
\text { estimates } \\
\text { (Barcelona } \\
\text { included) }\end{array}$ & $\begin{array}{l}\text { (b) } \\
\text { Combined } \\
\text { OLS } \\
\text { estimates } \\
\text { (Barcelona } \\
\text { included) }\end{array}$ & $\begin{array}{c}(\mathrm{c}) \\
\text { Combined } \\
\text { panel data } \\
\text { by fixed } \\
\text { effects } \\
\text { (Barcelona } \\
\text { included) }\end{array}$ & $\begin{array}{c}\text { (d) } \\
\text { combined } \\
\text { panel data } \\
\text { by fixed } \\
\text { effects } \\
\text { (Barcelona } \\
\text { excluded) }\end{array}$ \\
\hline Constant $(C T)$ & $\begin{array}{l}-0.043 \\
(-0.12)\end{array}$ & $\begin{array}{c}0.40 * * * \\
(5.00)\end{array}$ & & \\
\hline Population density, inhab./km² (POPDENS) & $\begin{array}{c}0.002921 * * * \\
(5.13)\end{array}$ & $\begin{array}{c}0.002495 * * * \\
(4.95)\end{array}$ & $\begin{array}{c}0.0000663 \\
(1.62)\end{array}$ & $\begin{array}{c}0.001399 * * \\
\quad(2.07)\end{array}$ \\
\hline time-distance to Barcelona, hours (BCNTIMDIS) & $\begin{array}{c}-0.00568 * * * \\
(-2.75)\end{array}$ & $\begin{array}{c}-0.00586^{* * *} \\
(-2.99)\end{array}$ & $\begin{array}{c}-0.00485^{* *} \\
(-2.24)\end{array}$ & $\begin{array}{c}-0.00418^{*} \\
(-1.94)\end{array}$ \\
\hline Huglin Index $(H U G)$ & $\begin{array}{c}0.00029 \\
(-0.71)\end{array}$ & & & \\
\hline Winkler Index $(E T I)$ & $\begin{array}{c}-0.00017 \\
(-0.56)\end{array}$ & & & \\
\hline Mean slope of land in \% $(S L O P)$ & & $\begin{array}{c}-0.0049 * * \\
(-2.18)\end{array}$ & & \\
\hline $\operatorname{Adj} \mathrm{R}^{2}$ & 0.396 & 0.415 & 0.902 & 0.907 \\
\hline Durbin - Watson & -- & -- & 2.10 & 2.18 \\
\hline Number of observations & 105 & 105 & 102 & 105 \\
\hline
\end{tabular}

Note: $t$-ratios are in brackets; $* * * 1 \%, * * 5 \%$ or $* 10 \%$ statistical confidence interval. Source: our own estimates, using the database taken from the historical statistical sources referred in the text, Graph 3 and Table 4.

\section{REFERENCES}

Agnoletti, M., ed. (2006) The Conservation of Cultural Landscapes (New York: CABI International Publishing).

Anonymous (1838) Itinerario de la mayor parte de los caminos y veredas de las cuatro provincias de Barcelona, Tarragona, Lérida y Gerona, con los pueblos y posadas situadas en las carreteras, y las horas que a paso de tropa distan unos de otros [Itinerary of most roads and paths of the four provinces of Barcelona, Tarragona, Lleida and Girona, with lodges in towns and roads, and the hours to pass troops far from each other] (Barcelona: Imprenta de Manuel Texero).

Anonymous (1932) La revisió dels contractes de parceria, per un propietari viticultor [The review of partnership contracts, for an owner viticulturist] (Barcelona: Altés Impressor).

Berger, A., and Maurel, F. (1980) La viticulture et l'économie du Languedoc du XVIIIe siècle a nos jours [Viticulture and the economy of the Languedoc from the $18^{\text {th }}$ century to the present] (Montpelier: Editions du Faoubourg).

Bertrán Soler, T. (1847) Itinerario descriptivo de Cataluña: comprende la descripción del antiguo Principado, su actual división territorial, militar, eclesiástica y judicial [Descriptive itinerary of Catalonia: Includes description of the former Principality, its current territorial division, military, judicial and ecclesiastical] (Barcelona: Imprenta de Oliveres). 
Boserup, E. (1981) Population and technological change. A study on long-term trends, (Chicago: Chicago University Press).

Campbell, B. M. S., and Overton, M., eds. (1991) Land, labour an livestock: historical studies in European agricultural productivity (Manchester: Manchester University Press).

Carmona J., Colomé, J., Pan-Montojo, J., and Simpson, J., eds., Viñas, bodegas y mercados. El cambio técnico en la vitivincultura española, 1850-1936 [Vineyards, wineries and markets. Technical change in the Spanish vine growing and winemaking] (Zaragoza: Prensas Universitarias de Zaragoza).

Carrión, P. (1932) Los latifundios en España: su importancia, origen, consecuencias y soluciones [Latifundia in Spain: its importance, origin, consequences and solutions] (reprinted in Barcelona: Ariel).

Crosby, A. W. (1972) The Columbian exchange: biological and cultural consequences of 1492 (Greenwood: Greenwood Publishing Comp).

Cussó, X., Garrabou, R., and Tello, E. (2006) Social metabolism in an agrarian region of Catalonia (Spain) in 1860-70: flows, energy balance and land use. Ecological Economics, 58: 49-65.

Diamond, J. M. (1997) Guns, germs, and steel: the fates of human societies (New York: W.W. Norton).

Diamond, J. M. (2006) Collapse: how societies choose to fail or succeed (New York: Penguin Books).

Dugrand, R. (1963) Villes et champagnes en Bas-Languedoc méditerranéen [Towns and countryside in the Mediterranean Bas-Languedoc] (París: Presses Universitaires de France).

Estasen, P. (1900) Cataluña: estudio acerca las condiciones de su engrandecimiento y riqueza [Catalonia: a study on the conditions of their wealth and aggrandizement] (Barcelona: F. Seix).

Fischer-Kowalski, M., Krausmann, F., and Smetschka, B. (2004): Modelling scenarios of transport across history from a socio-metabolic perspective. Review. A Journal of the Fernand Braudel Center for the Study of Economic, Historical Systems, and Civilizations, XXVII-4: 307-342.

Fischer-Kowalski, M., and Haberl, H. eds. (2007) Socioecological Transitions and Global Change. Trajectories of Social Metabolism and Land Use (Chentelham: Edward Elgar).

Fohlen, C. (1949) En Languedoc: vigne contre draperie [Vines against drapery in Languedoc]. Annales E. S. C., 4:290-297.

Frígola, V. (1824) Relación de los pueblos de que consta el Principado de Cataluña [List of the localities that make up the Principality of Catalonia] (Barcelona: Imprenta de la viuda e hijos de D. Antonio Brusi).

García de los Salmones, N. (1893) La invasión filoxérica en España y las cepas americanas [The Phylloxera invasion in Spain and the American strains] (Barcelona: Tipolitografía de Luis Tasso).

Garrabou, R. (2005) Conflict and environmental tension in the adoption of technological innovation in the agrarian sector. In Sarasúa, C., Scholliers, P., and Van Molle, L., eds. Land, Shops and Kitchens. Technology in the Food Chain in Twenty-century Europe (Turnhout: Brepols Publishers), pp. 30-41. 
Garrabou, R. ed. (1988) La crisis agraria de fines del siglo XIX [The agrarian crisis of the late nineteenth century](Barcelona: Crítica).

Garrabou, R., and Pujol, J. (1987) El canvi agrari a la Catalunya del segle XIX [The agrarian change in Catalonia during the nineteenth century]. Recerques, 19: 35-83.

Garrabou, R., Planas, J., and Saguer, E. (2000) Sharecropping and the Management of Large Rural Estates in Catalonia, 1850-1950. The Journal of Peasant Studies, 28: 89-108.

Garrabou, R., Tello, E., and Cussó, X. (2008): El cambio de usos del suelo en la comarca catalana del Vallès (1850-2000): fuerzas motoras y agentes rectores de la transformación del territorio [Land-use Change in the Catalan Vallès county (18502000): driving forces and ruling agents of the landscape transformation]. In Garrabou, R. and Naredo, J. M., eds., El paisaje en perspectiva histórica. Formación y transformación del paisaje en el mundo mediterráneo [Landscape in historical perspective. The making and transformation of landscapes in the Mediterranean world] (Zaragoza: SEHA/Prensas Universitarias de Zaragoza), pp. 233-258.

Garrabou, R., Tello, E., and Cussó, X. (in print ${ }^{\mathrm{a}}$ ): Ecological and Socio-economic functioning of the Mediterranean agrarian systems in the middle of the nineteenth century. A Catalan case study (the Vallès county, 1850-70). In Landsteiner, E., and Langthaler, E., eds. Agrosystems and Labour Relations in European Rural Societies (Middle Ages-20th Century). COST A35 Programme for the Study of European Rural Societies (Turnhout: Brepols Pub).

Garrabou, R., Tello, E., and Cussó, X. (in print ${ }^{b}$ ) Explaining agrarian specialization in an advanced organic economy: cereal production, consumption and trade in the province of Barcelona (Spain) in the mid-19th century. In Beaur, G., and Pinilla, V., eds., The impact of markets in the management of the rural land. COST A35 Programme for the Study of European Rural Societies (Turnhout: Brepols Pub.).

Garrier, G. (1989) Le Philoxéra. Une guerre de trente ans, 1870-1900 [The Philloxera. A Thirty Years' War, 1870-1900] (Paris: Édicions Albin Michel).

GEHR (1991) Estadísticas históricas de la producción agraria española, 1859-1935 [Historical Statistics of the Spanish agriculture, 1859-1935] (Madrid: Ministerio de Agricultura).

González de Molina, M. (2002) Environmental constraints on agricultural growth in $19^{\text {th }}$ century Granada (Southern Spain). Ecological Economics, 41: 257-270.

Grigg, D. (1982) The Dynamics of Agricultural Change. The historical experience (London: Hutchinson).

Heras, P., and Mas, C. (1994) Viticultura i Fil-loxera a l'últim terç del segle XIX. El cas de les Comarques de Tarragona [Viticulture and Philloxera during the last third of the $19^{\text {th }}$ century. The case of the Region of Tarragona] (Tarragona: Virgili Editor).

Herranz-Loncán, A. (2007) The spatial distribution of Spanish transport infrastructure between 1860 and 1930. The Annals of Regional Science, 41: 189-208.

Hornborg, A., McNeill, J. R., and Martínez Alier, J., eds. (2007) Rethinking Environmental History. World-System History and Global Environmental Change (New York: Altamira Press).

Johnson, Ch. H. (1995) The Life and the Death of Industrial Languedoc 1700-1920: the Politics of Deindustrialization (New York: Oxford U. P.) 
Junta Consultiva Agronómica (1922-23) Estadística de la producción de cereales y leguminosas en el año 1922 [Statistics on the production of cereals and leguminous crops in 1922] (Madrid: Imprenta de los Hijos de M. G. Hernández).

Koning, N. (1994) The Failure of Agrarian Capitalism. Agrarian politics in the United Kingdom, Germany, the Netherlands and the USA, 1846-1919 (London: Routledge).

Krausmann, F., Schandl, H., and Sieferle, R. P. (2008) Socio-ecological regime transitions in Austria and the United Kingdom. Ecological Economics, 68: 187-201.

Little, D. (2008) Causation in Meso-History; Epistemological Issues in Economic History. [Accessed 27 May 2009] Available on-line URL: http://www.changingsociety.org/ChangingSociety/Research page.html.

Llovet Mont-Ros, J. (1948) Contribución al estudio general de la agricultura en la provincia de Barcelona [Contribution to the study of agriculture in the province of Barcelona] (Barcelona: Anales de la Escuela de peritos Agrícolas y de Especialidades Agropecuarias y de los Servicios Técnicos de Agricultura).

Marull, J., Pino, J. and Tello, E. (2008) The Loss of Landscape Efficiency: a landscape ecology analysis of land-use changes in Western Mediterranean agriculture over the last 150 years (the Vallès county, Catalonia, 1853-2004). Global Environment. Journal of History and Natural and Social Sciences, 2: 112-150.

Martínez Quintanilla, P. (1865) La Provincia de Gerona: datos estadísticos sobre su territorio, población, beneficiencia, baños y aguas minerales [The Province of Girona: statistical data on its territory, population, welfare, baths and mineral waters] (Girona: Impr. de F. Dorca sucesor de J. Grases).

McNeill, J. (2000) Something new under the sun. An environmental history of the twentieth century (London: Penguin).

McNeill, W. H. (1976) Plagues and peoples (New York: Anchor Press).

Moreno Ramírez, P. (1858) Estadística Territorial de la província de Barcelona [Land-use Statistics in the province of Barcelona] (Madrid: Dirección General del Instituto Geográfico y Estadístico, Instituto Geográfico Nacional, manuscript 1,733).

Olarieta, J. R., Rodríguez-Valle, F., and Tello, E. (2008) Preserving and destroying soils, transforming landscapes: Soils and land-use changes in the Vallès County (Catalunya, Spain) 1853-2004. Land Use Policy, 25: 474-484.

Pan-Montojo J. (1994) La bodega del mundo. La vid y el vino en España, 1800-1936 [The cellar of the world. The vine and wine in Spain, 1800-1936] (Madrid: Alianza Editorial).

Pascual, P. (1999) Los caminos de la era industrial. La construcción y financiación de la Red Ferroviaria Catalana, 1843-1898 [The roads of the industrial age. Building and financing the Catalan Railway Network, 1843-1898] (Barcelona: Edicions de la

Universitat de Barcelona/Fundación Ferrocarriles Españoles).

Paul, H. W. (1996) Science, vine and wine in modern France (Cambridge: Cambridge U. P.).

Persson, K. G. (1999) Grain Markets in Europe, 1500-1900 (Cambridge: Cambridge U. P.).

Pinilla, V., and Ayuda, M. I. (2007) The Internacional Wine Market, 1850-1938. An Opportunity for Export Growth in Southern Europe? In Campbell, G., and Guibert, N. eds., Wine, Society and Globalization. Multidisciplinary Perspectives on the Wine Industry (New York: Palgrave Macmillan), pp. 179-199.

Piqueras, C. (2005) La filoxera en España y su difusión espacial: 1876-1926 [The Phylloxera in Spain and its spatial distribution]. Cuadernos de Geografía, 77: 101136. 
Planas, J. (2003) Cooperativismo y difusión del cambio técino en la agricultura. La contribución de las cámaras agrícolas (Cataluña, 1890-1930) [Cooperatives and diffusion of technical change in agriculture. The contribution of agricultural chambers]. Historia Agraria, 30: 87-117.

Roig Armengol, R. (1890) Memòria Acompanyatória al Mapa Regional Vinícola de la provincia de Barcelona [Report accompanying the Vineyard Regional Map of the province of Barcelona] (Barcelona: La Academia).

Sánchez, A., and Nadal, J. (1998) En los orígenes del éxito algodonero catalán [In the origins of the Catalan cotton success]. In De la fibre à la fripe. Le textile dans la France meridionale et l'Europe mediterraneene, XVIIIe-XXe siècles [From the fibre to the frippery. Textiles in southern France and Mediterranean Europe, 18th-20th centuries] (Montpelier: Université Paul Valéry), pp. 35-57.

Sieferle, R. P. (2001) The Subterranean forest: energy systems and the Industrial Revolution (Cambridge: The White Horse Press).

Simpson, J. (1995) Spanish agriculture: the long siesta, 1765-1965 (Cambridge: Cambridge U. P.).

Simpson, J. (1999): The Agrarian crisis in late nineteenth century Spain: a reconsideration Documento de trabajo $\mathrm{n}^{\mathrm{o}} 3$ de la serie de historia económica e instituciones, Universidad Carlos III, Madrid.

Sociedad Económica de Amigos del País de Barcelona (1888) Contestación a la encuesta de la La Crisis Agrícola y Pecuaria [Answer to the survey on The Agricultural and Livestock Crisis] (Madrid: Establecimiento Tipográfico Sucesores de Rivadeneyra).

Sudrià, C., and Pascual, P. (1999) Financing a railway mania: capital formation and the demand for money in Catalonia. Financial History Review, 6: 127-145.

Tello, E., Garrabou, R., and Cussó, X. (2006) Energy Balance and Land Use. The Making of and Agrarian Landscape from the Vantage Point of Social Metabolism (the Catalan Vallès county in 1860/70). In Agnoletti, M., ed., The Conservation of Cultural Landscapes (New York: CABI International Publishing), pp. 42-56.

Tello, E., Garrabou, R., Olarieta, J. R. and Cussó, X. (2006) From integration to abandonment. Forest managment int the Mediterranean agro-ecosystems before and after the 'green revolution' (The Vallès County. Catalonia, Spain, 1860-1999). In Parrotta, J., Agnoletti, M, and Johann, E. eds., Cultural heritage and sustaintable forest managment: The role of traditional knowledge (Warsaw: Ministerial Conference for the Protection of Forest in Europe/IUFRO), pp. 339-346.

Tonnietto, J. and Carbonneau, A. (2004) A multicriteria climatic classification system for grape-growing regions worldwide. Agricultural and Forest Metereology, 124: 8197.

Valls, F. (1996) La Dinàmica del canvi agrari a la Catalunya interior: l'Anoia, 1720-1860 [The dynamics of agricultural change in the inner Catalonia: the Anoia county, 1720-1860] (Barcelona: Publicacions de 1'Abadia de Montserrat).

Valls, F. (2003) La Catalunya atlàntica. Aiguardent $i$ teixits a l'arrencada industrial catalana [The Atlantic Catalonia. Brandy and textiles in the start of the Catalan industry] (Vic: Eumo).

Valls, F. (2004) Viticulture et industrialisation en Europe du Sud: les cas du Languedoc, du Portugal et de la Catalogne [Viticulture and industrialization in Southeast Europe: the case of Languedoc, Portugal and Catalonia]. Domiti , 5:41-51. 
Vries, J. de (2001) Economic growth before and after the Industrial Revolution. A modest proposal. In Prak, M., ed., Early Modern Capitalism. Economic and social change in Europe, 1400-1800 (London: Routledge), pp. 177-194.

Williamson, J. (2006) Globalization and the poor periphery before 1950 (Cambridge: The MIT Press).

Wrigley, E. A. (2004) Poverty, Progress, and Population (Cambridge: Cambridge U. P.).

Van Zanden, J. L. (1991) The first green revolution. The growth of production and productivity in European agriculture, 1870-1914. Economic History Review, XLIV: 215-239. 